\title{
Метод создания моделей самолетов с помощью систем CAD/CAM/CAE и аддитивных технологий
}

\author{
Национальный аэрокосмический университет им. Н. Е. Жуковского \\ "Харьковский авиационный институт» \\ ЗАО «Верифрикационные модели»
}

\begin{abstract}
Проведен анализ наиболее применимых в машиностроении аддитивных технологий моделирование методом послойного плавления, селективное лазерное спекание, лазерная стереолитография, прямое лазерное спекание металлов. Представлен метод создания моделей самолетов с помощью систем CAD/CAM/CAE и аддитивных технологий. Рассмотрены результаты применения селективного лазерного спекания и послойного наплавления для изготовления моделей учебно-тренировочных самолетов.
\end{abstract}

Ключевые слова: аддитивные технологии, селективное лазерное спекание, учебнотренировочный самолет, модель, мастер-геометрия.

При проектировании и производстве конкурентоспособной авиационной техники необходимо применять современные достижения компьютерной техники и технологии CAD/CAM/CAE.

Аддитивные технологии в авиационной промышленности могут использоваться для моделирования, прототипирования и изготовления деталей воздушных судов [1].

Аддитивные технологии - обобщенное название технологий производства методом послойного добавления (add, англ. - добавлять) материала по данным цифровой модели (CAD-модели). Их также можно называть технологиями послойного синтеза в отличие от "вычитающих" производственных технологий [1].

Рекомендованы два основных термина - Additive Fabrication (AF), Additive Manufacturing (AM). Часто в популярной научно-технической литературе и разговорной речи профессионалов встречаются сочетания слов "3D-печать", 3Dпринтер" или "3D-принтинг". Главной особенностью или основной ценностью аддитивных технологий можно называть сокращение времени выхода на рынок новой продукции [1].

Цифровые 3D-технологии открыли уникальные возможности воспроизведения сложнейших пространственных форм, объектов и инженерных конструкций. В наши дни AF-технологии используют повсеместно. Научно-исследовательские организации с их помощью создают уникальные материалы и ткани, промышленные гиганты используют 3D-принтеры для ускорения производства уникальной продукции, архитектурные и конструкторские бюро нашли в 3D-печати огромный потенциал для быстрой реализации идей. В настоящее время аддитивным способом изготавливают инструменты, детали авиалайнеров, спутников, ракет, медицин- 
ские протезы, имплантанты и т. д. Все это свидетельствует о том, что AF постепенно приобрели статус стратегически важных и приоритетных технологий [2].

В машиностроительных отраслях наиболее распространенными АМтехнологиями являются следующие [1]:

1. Моделирование методом послойного наплавления (англ. Fused deposition modeling (FDM)) - технология аддитивного производства, широко используемая при создании трехмерных моделей, при прототипировании и в промышленном производстве.

Технология FDM подразумевает создание трехмерных объектов путем нанесения последовательных слоев материала, повторяющих контуры цифровой модели. Экструдер 1 перемещается в горизонтальной и вертикальной плоскостях и создаёт модель слой за слоем 2 на платформе 3 (рис. 1). Как правило, в качестве материалов для печати выступают термопластики, поставляемые в виде катушек нитей или прутков.

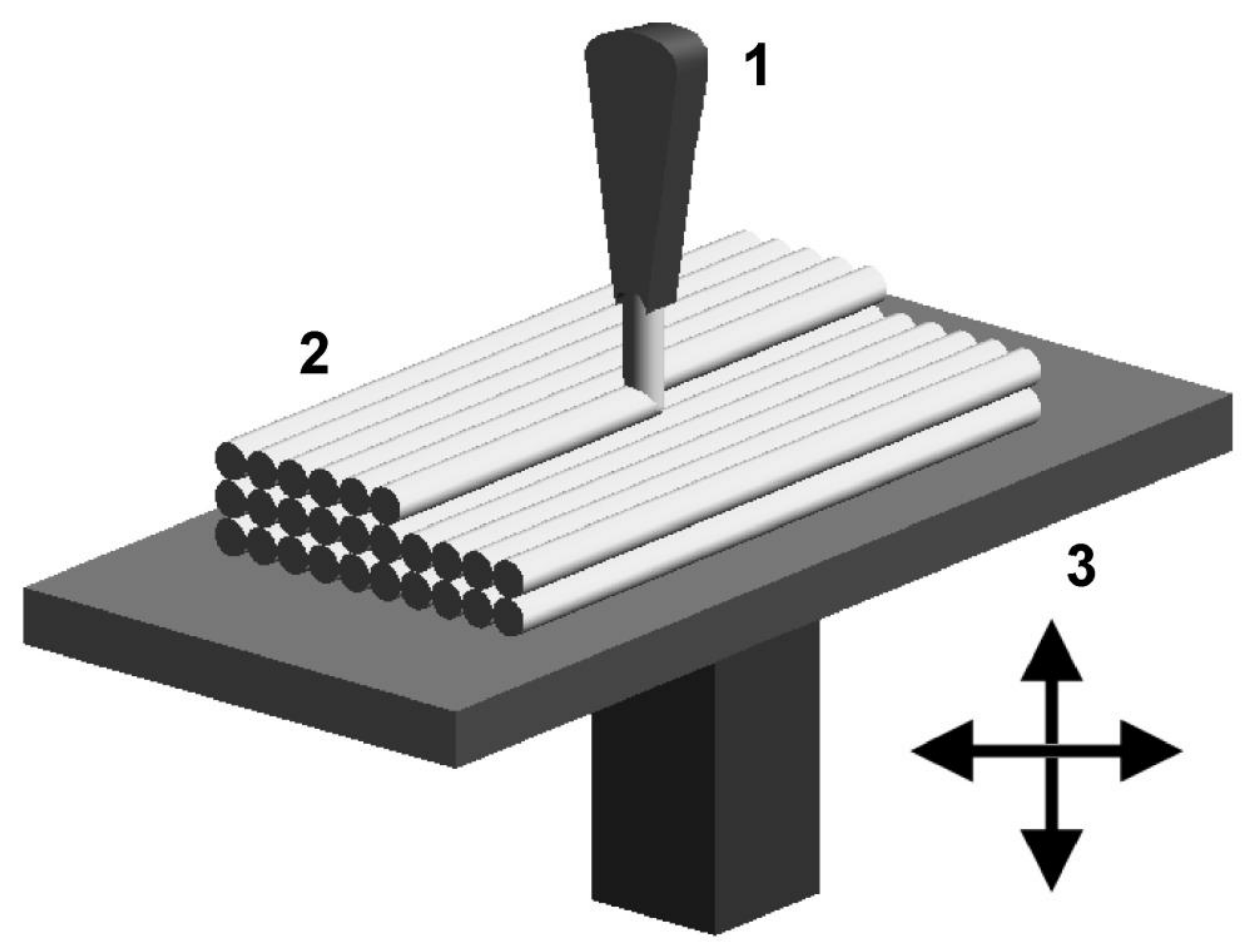

Рис. 1. Схема процесса моделирования методом послойного наплавления

Преимуществами FDM-технологии являются [3]:

- относительная простота процесса и доступность оборудования;

- большой выбор и невысокая цена исходных материалов.

К недостаткам можно отнести [3]:

- дополнительные затраты материала на поддержки;

- необходимость дополнительной механической обработки поверхностей.

2. Селективное лазерное спекание (Selective Laser Sintering (SLS)) - послойное спекание порошковых материалов. Суть технологии заключается в следующем. Модельный материал - полистирольный порошок с размером частиц 
50...150 мкм, накатывается специальным роликом на рабочую платформу, установленную в герметичной камере с атмосферой инертного газа (азота). Лазерный луч «пробегает» по сечениям CAD-модели. Здесь лазерный луч является источником тепла, под воздействием которого происходит спекание частичек полистирола (рабочая температура - около $120^{\circ} \mathrm{C}$ ). Затем платформа опускается, и новая порция порошка накатывается поверх отвержденного, в результате формируется новый слой, который также спекается с предыдущим (рис. 2).

Процесс повторяется до полного построения модели, которая в конце процесса оказывается заключенной в массив неспеченного порошка.

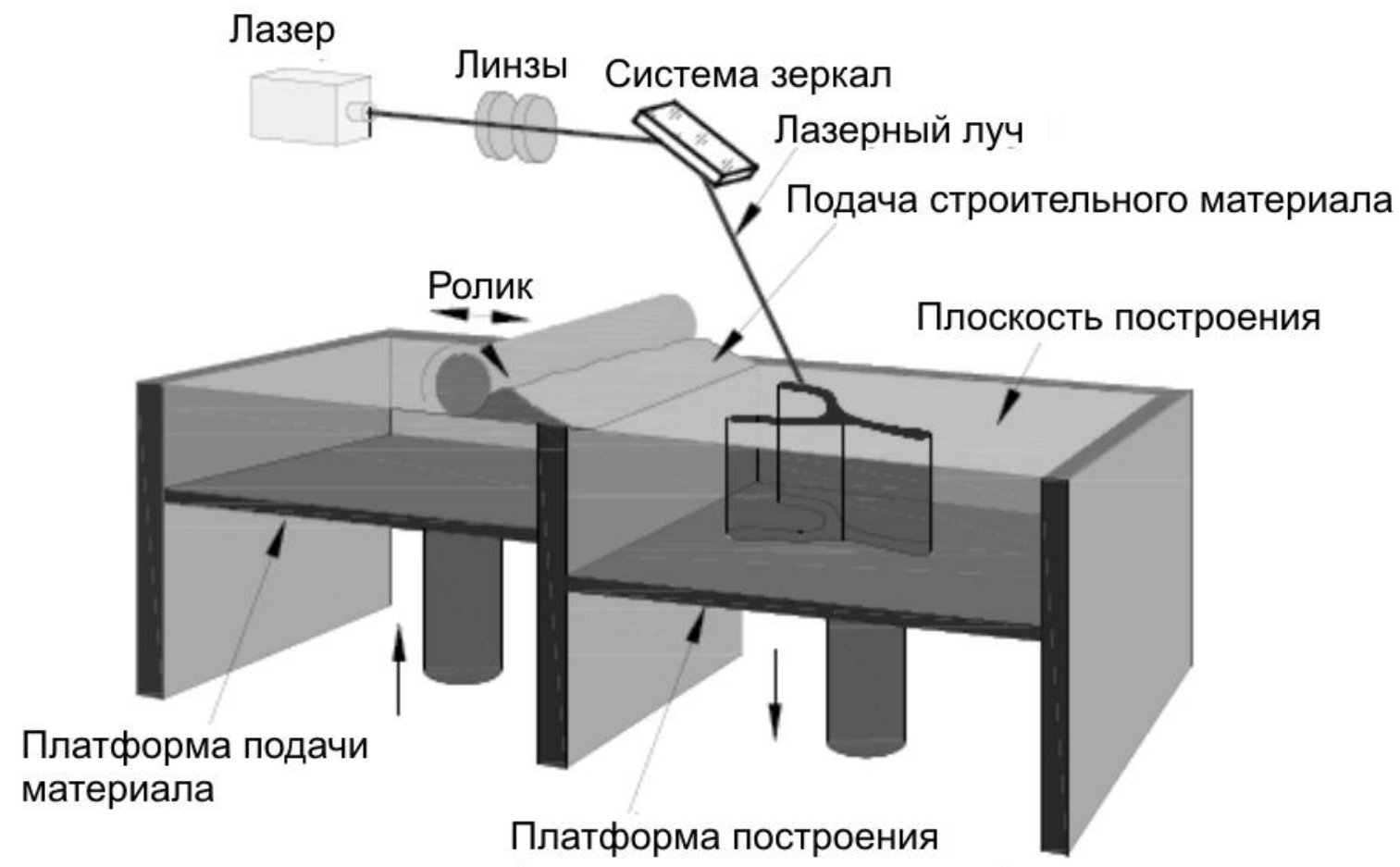

Рис. 2. Схема процесса моделирования методом селективного лазерного спекания

Преимущества SLS технологии [3]:

- высокая прочность получаемых изделий;

- возможность построения изделия с движущимися частями за один производственный цикл, что приводит к сокращению расходов, экономии трудозатрат при сборке;

- построение нескольких моделей одновременно;

- низкие деформации и напряжения в создаваемой модели;

- минимальные сроки окончательной обработки.

К недостаткам технологии SLS относятся [3]:

- высокая сложность и стоимость оборудования и исходного материала;

- высокие затраты энергии. 
3. Лазерная стереолитография (Steriolithography Apparatus (SLA)) - технология, основанная на фотоинициированной лазерным излучением полимеризации фотополимеризующейся композиции (ФПК). Этот метод отличается от других тем, что в нем используют в качестве «строительного материала» не порошки, а фотополимеры в жидком состоянии. В ёмкость с жидким фротополимером помещают сетчатую платформу (элеватор), на которой происходит "выращивание" прототипа (рис. 3).

Стереолитография считается наиболее точной аддитивной технологией. SLA принтеры используют преимущественно для изготовления прототипов, макетов и дизайнерских компонентов повышенной точности с высоким уровнем детализации, так как процесс построения происходит при комнатной температуре в отсутствие термических нагрузок. SLA-машины применяют для получения: литейных моделей; мастер-моделей; литейных форм и литейной оснастки.

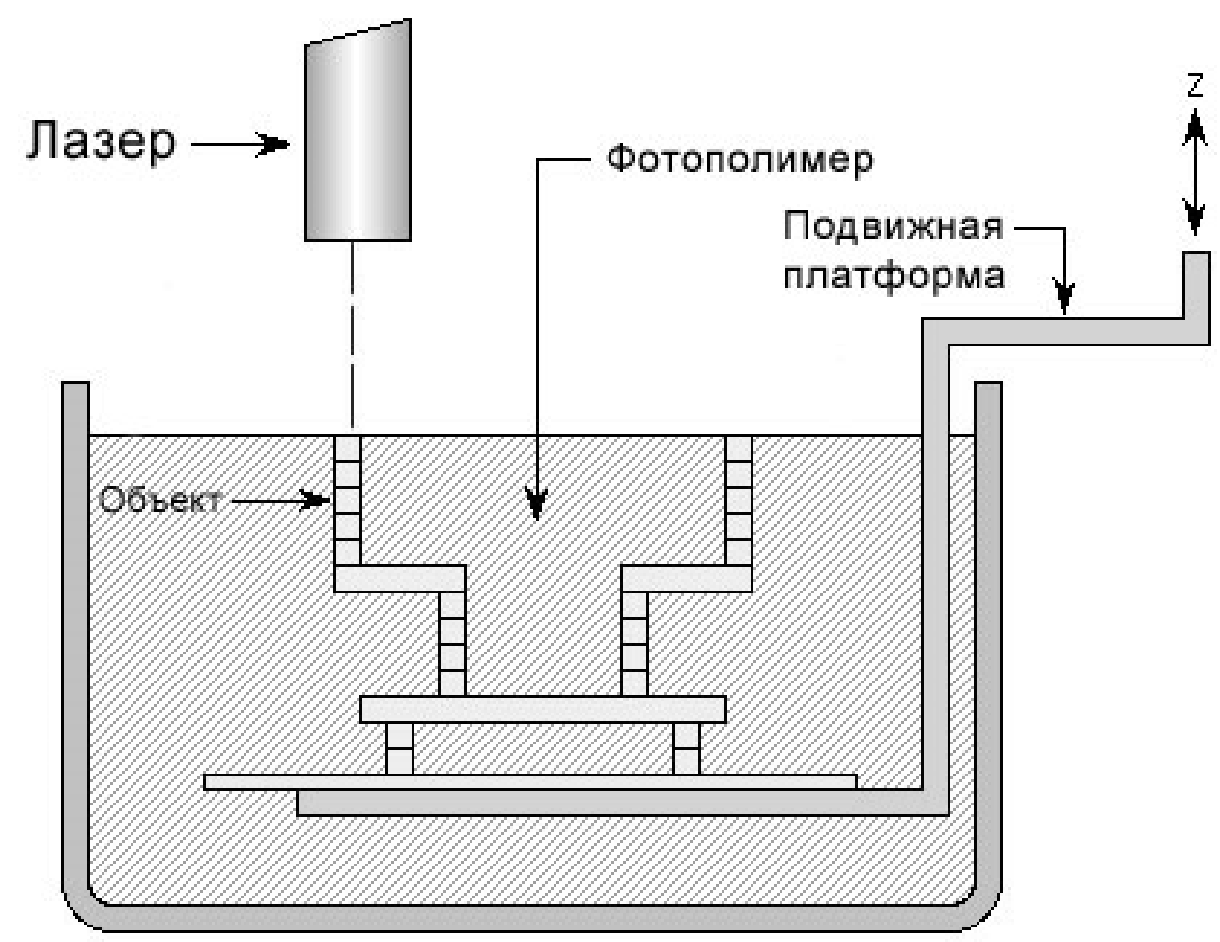

Рис. 3. Схема процесса моделирования методом лазерной стереолитографии

Преимущества технологии SLA:

- высокая точность изготовления;

- возможность изготовления сложных изделий;

- малый расход материала на поддержки.

Недостатками технологии является высокая стоимость оборудования и расходного материала.

4. Прямое лазерное спекание металлов (Direct Metal Laser Sintering (DMLS)) - послойное лазерное спекание металлопорошковых композиций. Тонкие слои мелкодисперсного металлического порошка равномерно распределяют на подложке, обычно металлической, которая крепится к столу, перемещаемому по 
вертикальной оси. Процесс происходит внутри камеры с инертным газом (аргоном, азотом). Каждый слой сплавляется путем избирательного плавления порошка мощным лазерным лучом. Энергия лазерного луча достаточно интенсивна, чтобы обеспечить полное плавление частиц с образованием твердого металла. Процесс повторяется слой за слоем (рис. 4).

Среди материалов, используемых в этом процессе, - медь, алюминий, нержавеющая сталь, инструментальная сталь, кобальтовый хром, титан и вольфррам.

Преимущества метода [4,5]:

- отсутствие необходимости поддержек;

- возможность создания изделий высокой сложности;

- минимизация необходимости механической обработки изделия;

- возможность создания нескольких изделий одновременно.

К недостаткам можно отнести:

- более пористую структуру и низкую прочность готового изделия по сравнению с традиционными методами обработки металла (точение, фррезерование и др.);

- высокую стоимость оборудования и исходных материалов.
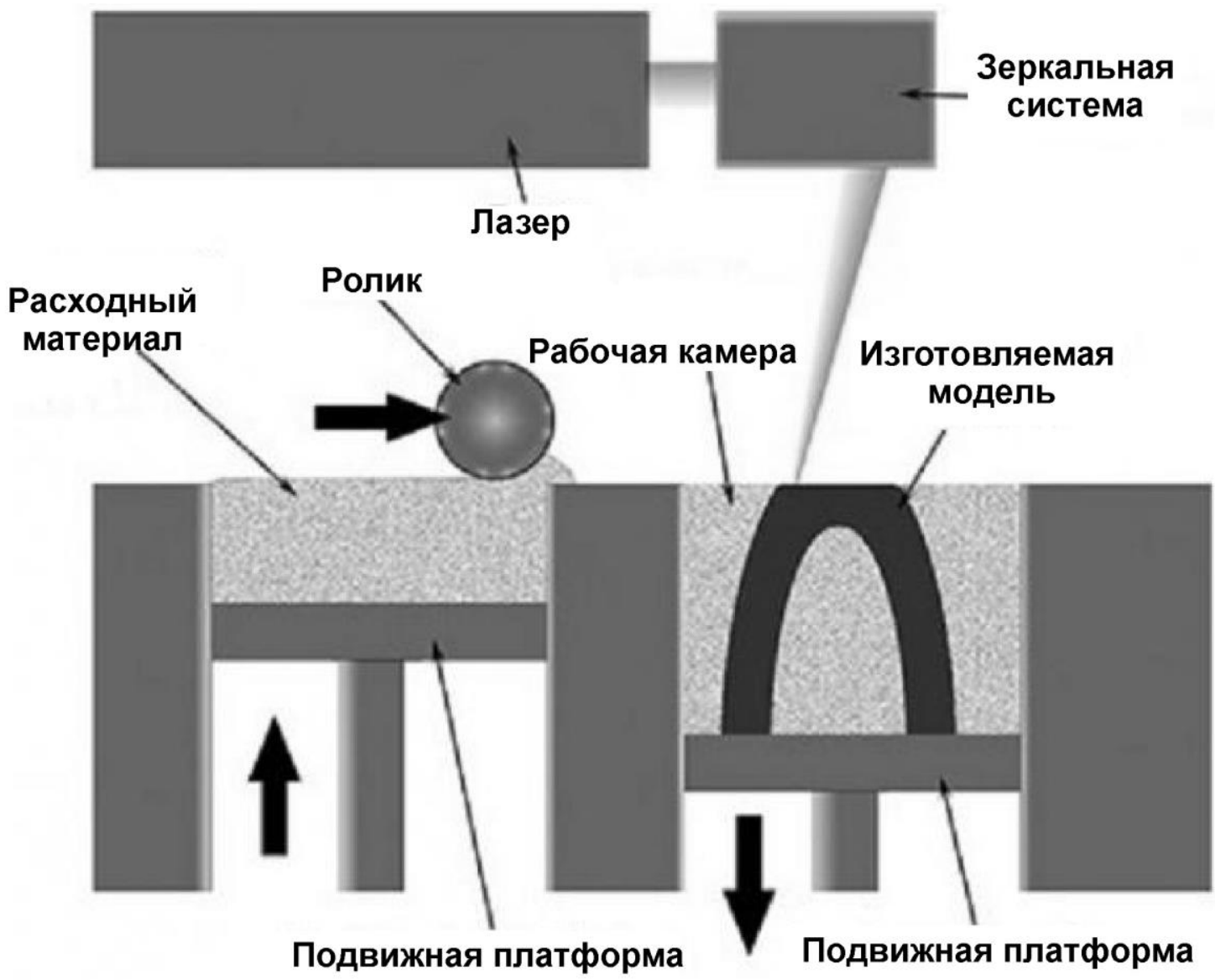

Рис. 4. Схема процесса моделирования методом прямого лазерного спекания металлов 
Целью работы является разработка метода создания моделей самолетов с применением систем CAD/CAM/CAE и аддитивных технологий.

Метод создания моделей самолетов с использованием систем CAD/CAM/CAE и аддитивных технологий (рис. 5) включает в себя разработку чертежей общего вида (рис. 6, 7) и создание электронной модели поверхности самолета [6] (рис. 8), подготовку твердотельной модели, деление твердотельной модели на составляющие с учетом особенностей выбранного способа изготовления (рис. 9), преобразование модели в формат STL (рис. 10), изготовление составляющих модели с помощью аддитивных технологий, сборку составляющих, обработку поверхности, покраску модели.

Создание электронной модели поверхности проектируемого самолета с помощью систем CAD/CAM/CAE

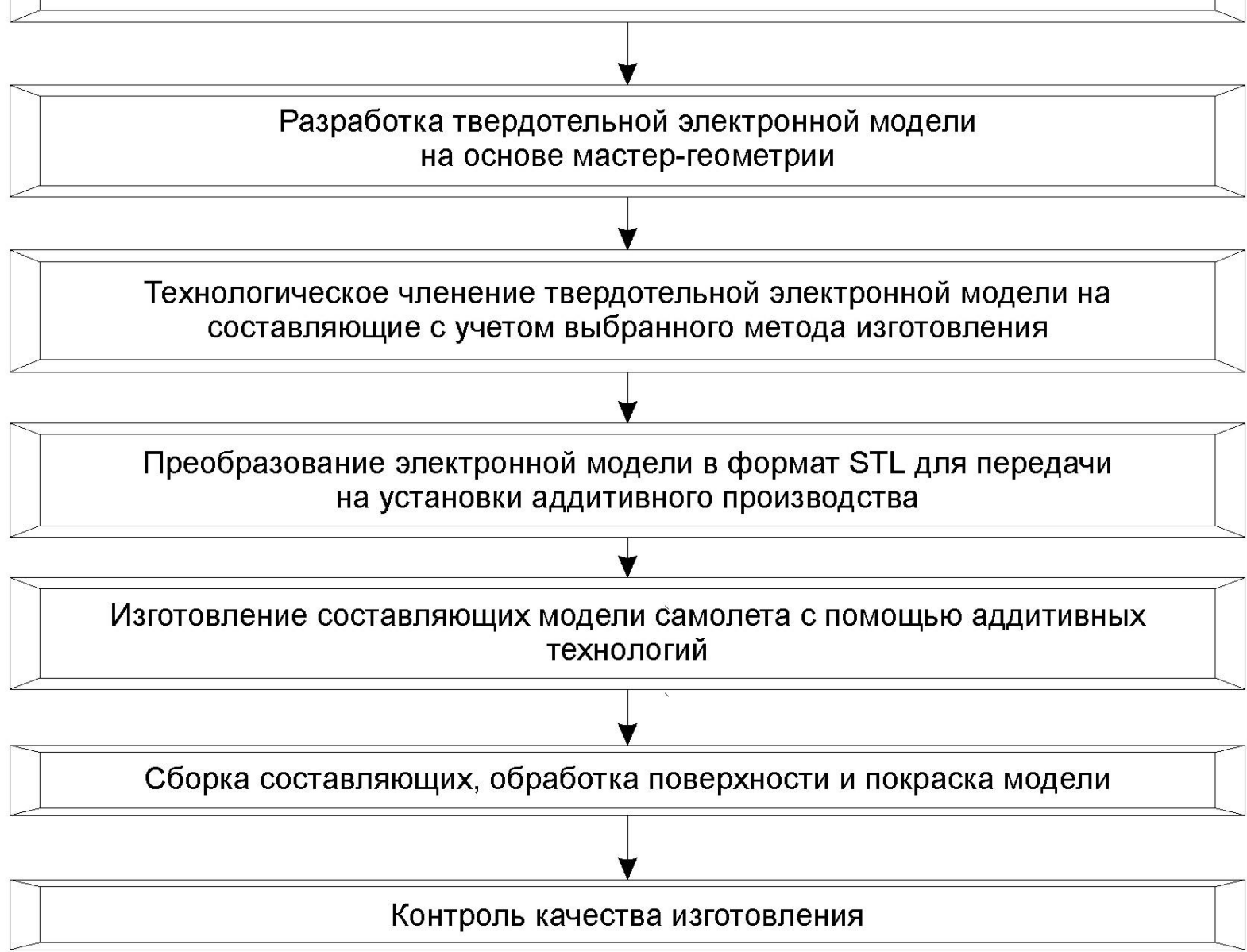

Рис. 5. Метод создания моделей самолетов с применением систем CAD/CAM/CAE и аддитивных технологий

Аддитивные технологии селективного лазерного спекания (SLS) и послойного наплавления были применены для изготовления моделей учебнотренировочных самолетов (УТС) [7] - двухдвигательного взлетной массой 8090 кг (рис. 6) и однодвигательного взлетной массой 2264 кг (рис. 7). 

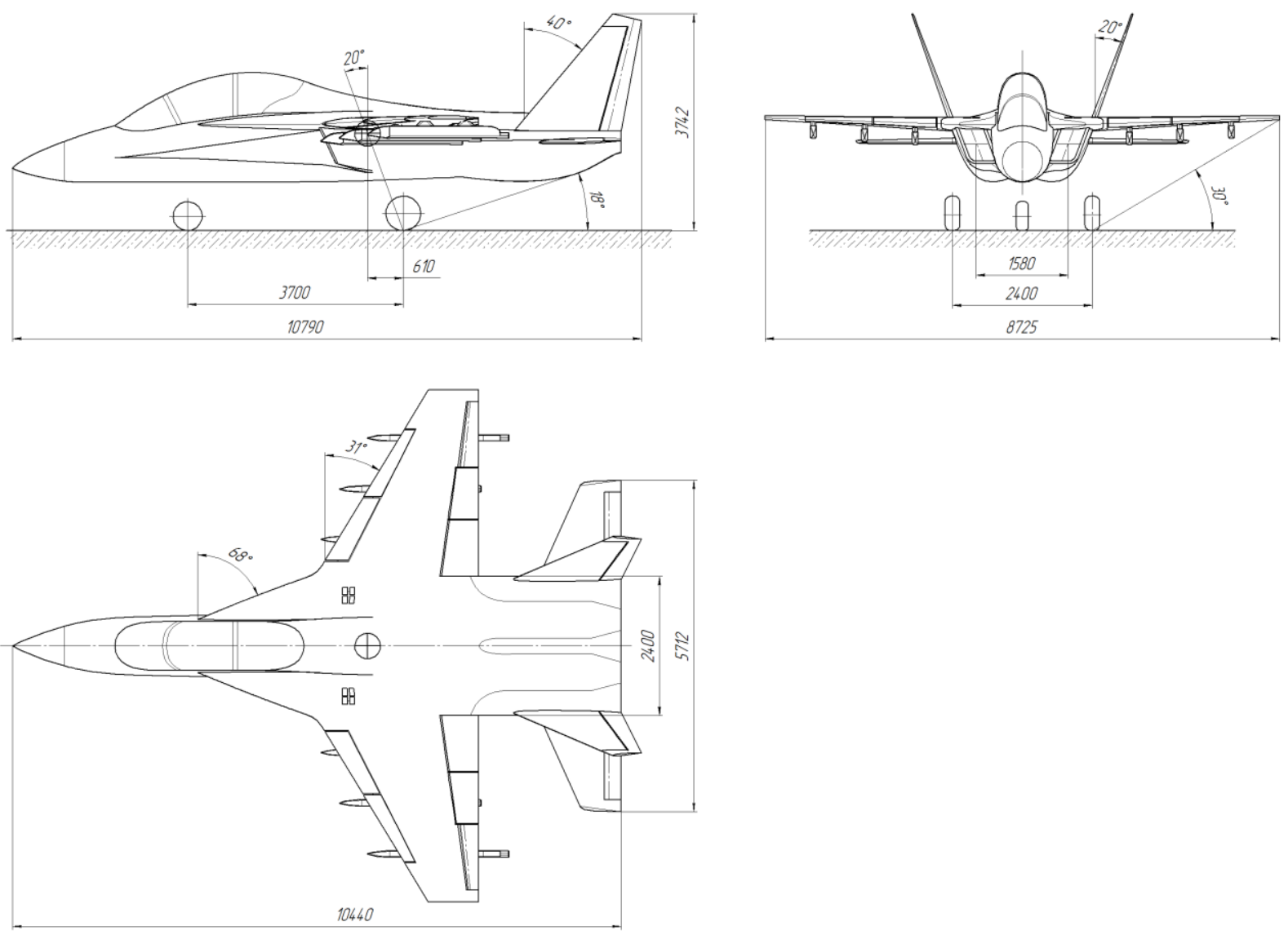

Рис. 6. Фрагмент общего вида УТС взлетной массой 8090 кг
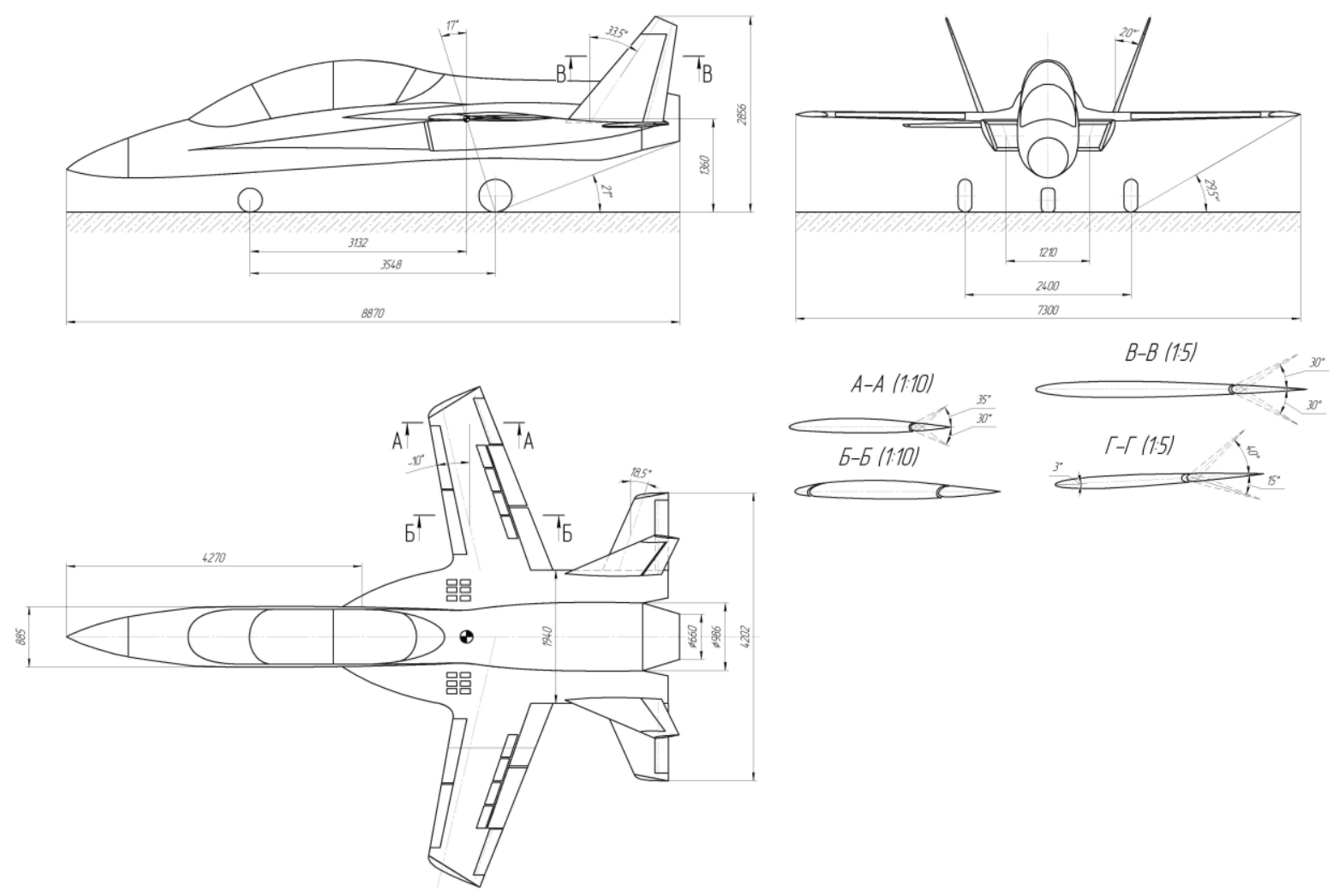

Рис. 7. Фрагмент общего вида УТС взлетной массой 2264 кг 


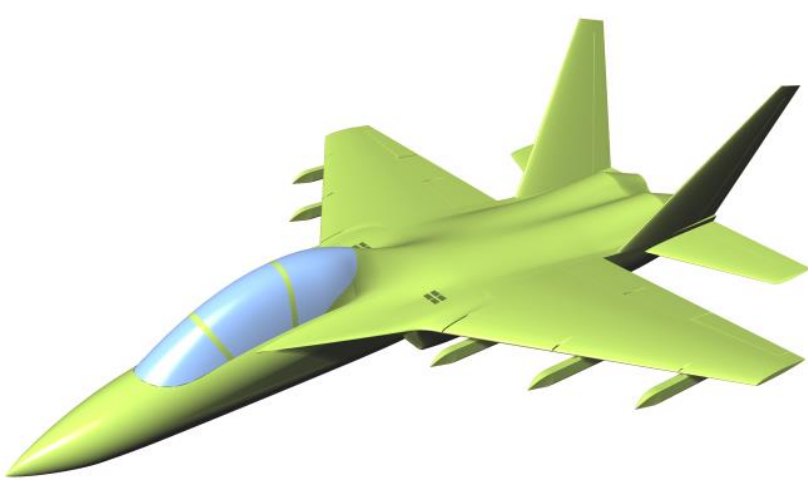

a

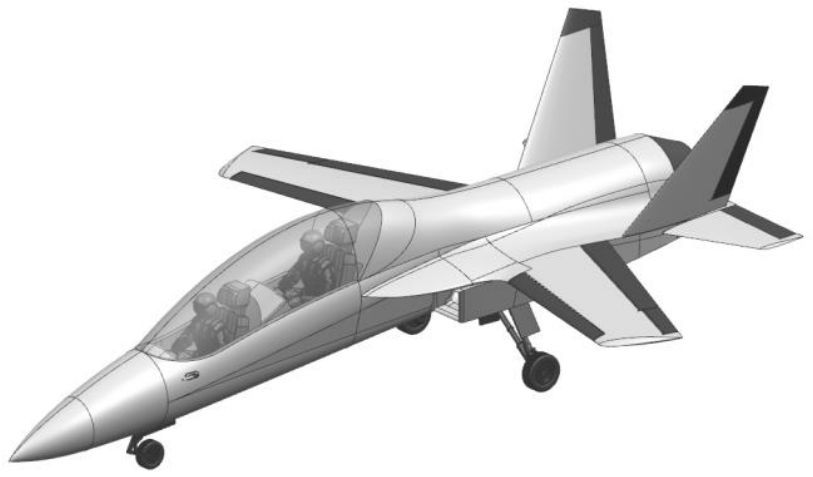

6

Рис. 8. Мастер-геометрия УТС взлетной массой 8090 кг (а) и взлетной массой 2264 кг (б)

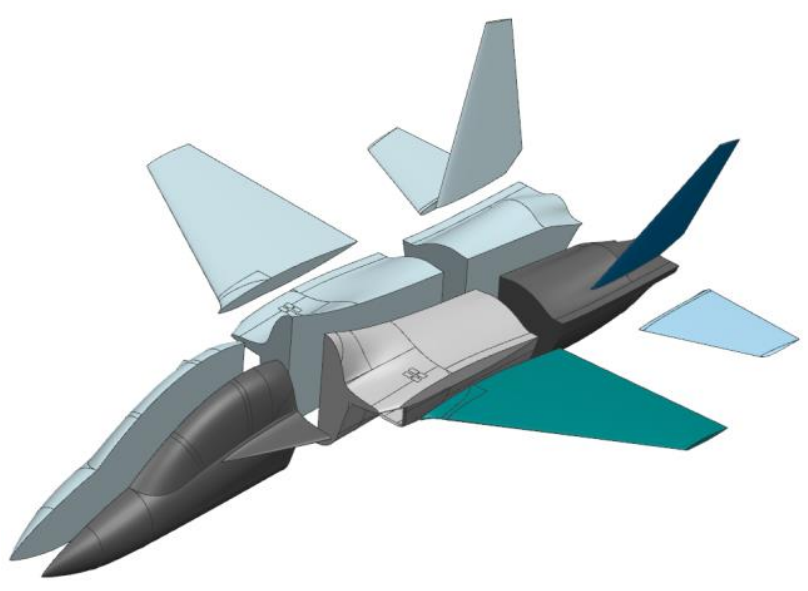

a

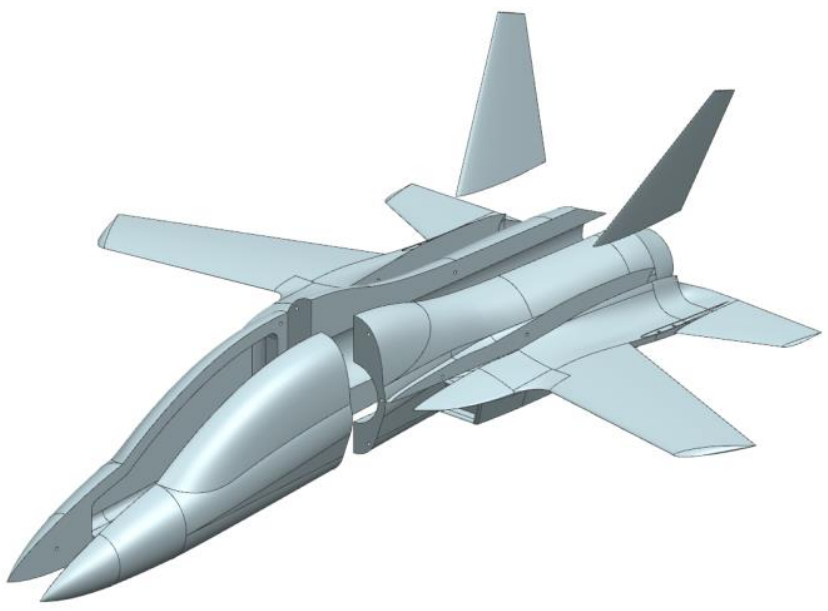

б

Рис. 9. Твердотельные электронные модели элементов УТС взлетной массой 8090 кг (а) и взлетной массой 2264 кг (б)

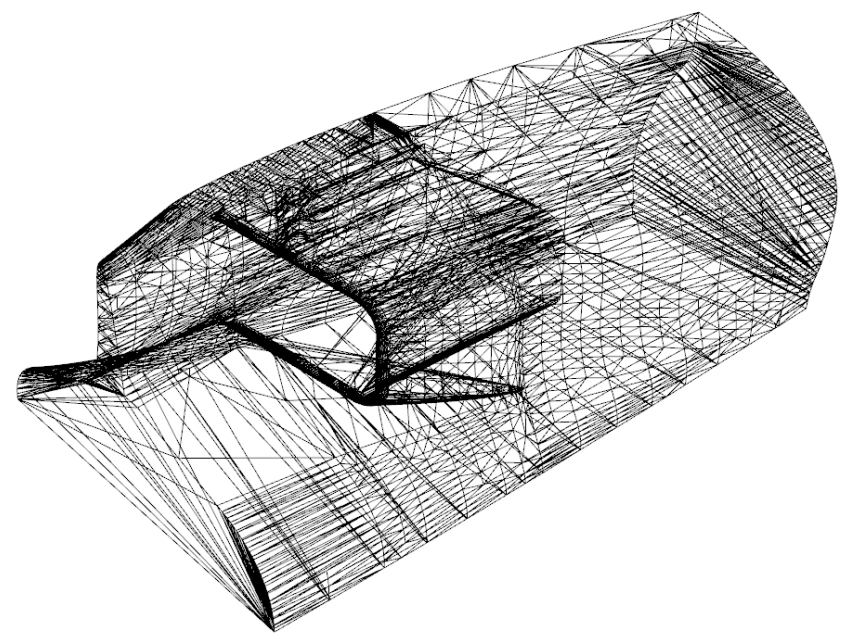

a

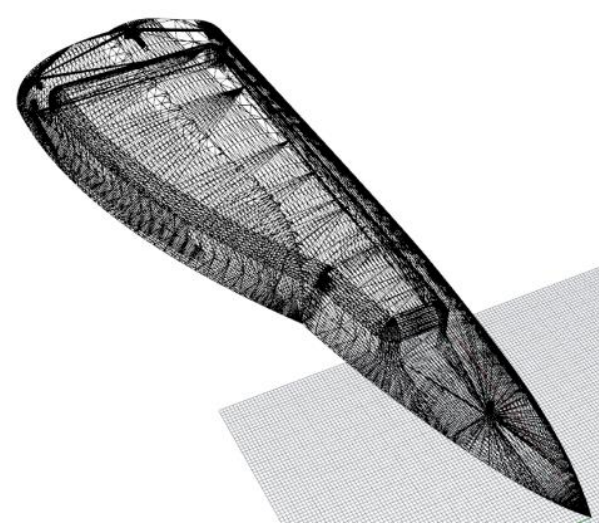

6

Рис. 10. Модели в фрормате STL центральной (а) и носовой (б) частей фюзеляжа 
STL (от англ. stereolithography) - формат файла, используемый для хранения трёхмерных моделей объектов для использования в аддитивных технологиях. Информация об объекте хранится как список треугольных граней, которые описывают его поверхность, и их нормалей.

Затем по созданной электронной модели на установке Vangaurd HS (рис. 11) спеканием порошка из полиамида получена модель УТС (рис. 12).

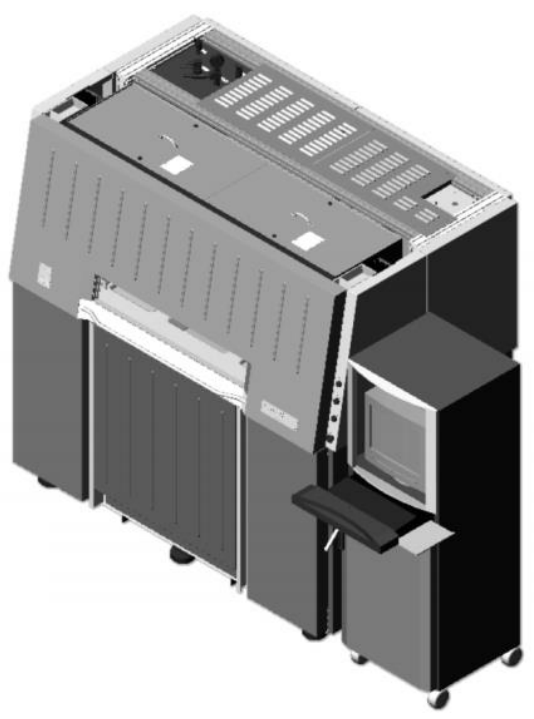

Рис. 11. Установка Vangaurd HS

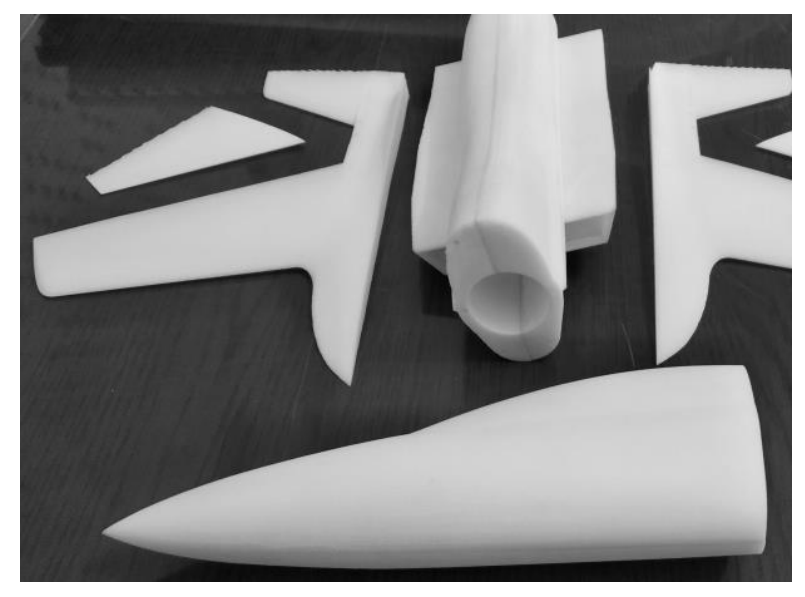

Рис. 12. Составляющие элементы модели УТС

Технические данные Vangaurd HS:

- максимальные размеры - 330×270×400 мм;

- скорость построения - $8 \ldots 10 \mathrm{~mm} / 4$;

- точность построения - минус $0,3 \ldots+0,3$ мм (на 100 мм).

Модели после сборки, механической обработки поверхности и покраски показаны на рис. 13, 14.

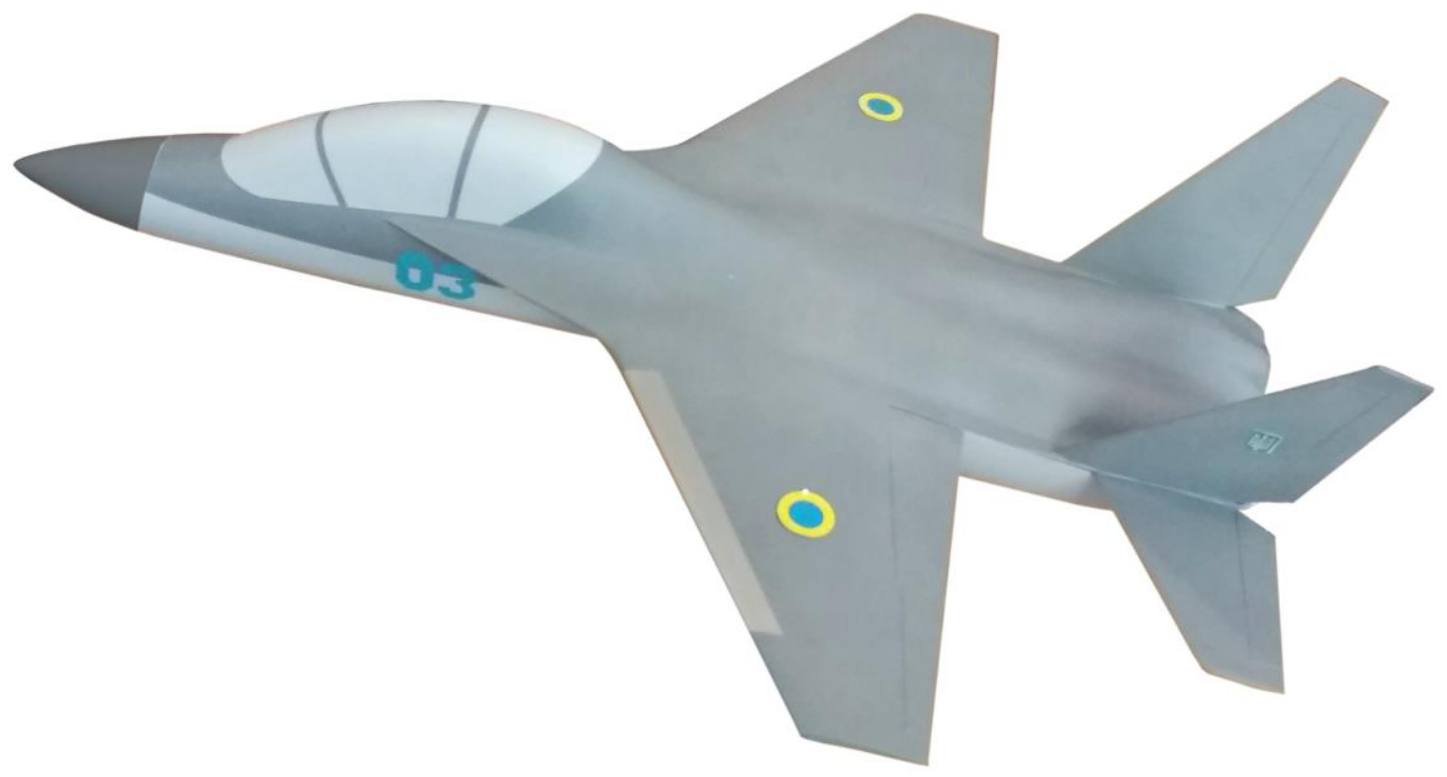

Рис. 13. Модель УТС взлетной массой 8090 кг 


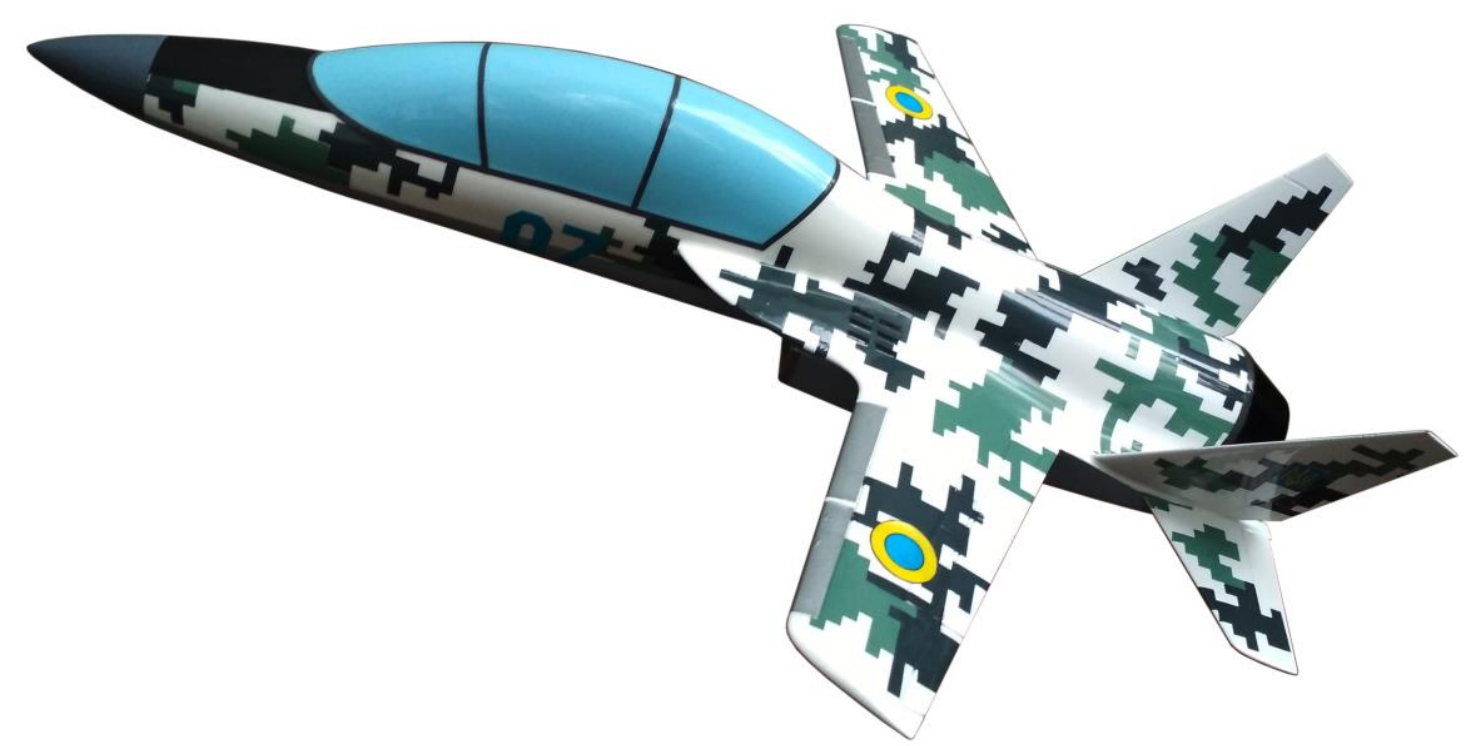

Рис. 14. Модель УТС взлетной массой 2264 кг

\section{Выводы}

Разработан метод создания моделей самолетов с применением систем CAD/CAM/CAE и аддитивных технологий (моделирование методом послойного плавления, селективное лазерное спекание, лазерная стереолитография, прямое лазерное спекание металлов).

Метод апробирован при изготовлении макетов учебно-тренировочных самолетов с применением селективного лазерного спекания и послойного наплавления.

Использование аддитивных технологий позволяет переходить непосредственно от CAD фрайла к пластиковым и металлическим изделиям или оснастки за значительно меньший промежуток времени, чем при традиционной механической обработке.

\section{Список литературы}

1. Зленко, М.А. Аддитивные технологии в машиностроении [Текст]: пособие для инженеров / М.А. Зленко, М.В. Нагайцев, В.М. Довбыш. - М.: ГНЦ РФ ФГУП «НАМИ», 2015. - 220 c.

2. Спрукуль, В. О. Внедрение аддитивных технологий [Текст] / В. О. Спрукуль // Актуальные проблемы авиации и космонавтики. - Т. 3. - Красноярск, 2017. - C. 304-306.

3. Литунов, С.Н. Обзор и анализ аддитивных технологий. Ч. 1 [Текст] / С.Н. Литунов, В. С. Слободенюк, Д. В. Мельников // Омский научный вестник. - 2016. - № 1 (145). - С. 12-17.

4. Специальные технологии и материалы порошковой металлургии [Текст] / Д. С. Кива, С. А. Бычков, О. Ю. Нечипоренко и др. - К. : КВІЦ, 2014. - 664 с.

5. Порошковая металлургия на рубеже веков: новые аспекты, понятия и определения [Текст] / Д. С. Кива, С. А. Бычков, О. Ю. Нечипоренко и др. - К. : КВІЦ, 2014. - 192 с.

6. Гребеников, А.Г. Метод создания мастер-геометрии учебно-тренировочного самолета [Текст] / А. Г. Гребеников, А. М. Гуменный, А. А. Соболев // Открытые информационные и компьютерные интегрированные технологии: сб. 
науч. тр. Нац. аэрокосм. ун-та им. Н. Е. Жуковского «ХАИ». - Харьков, 2016. -Вып. 74. - C. $5-11$.

7. Аванпроект реактивного учебно-тренировочного самолета для первоначального обучения [Текст] / А. К. Мялица, А. Г. Гребеников, А. М. Гуменный и др.// Открытые информационные и компьютерные интегрированные технологии: сб. науч. тр. Нац. аэрокосм. ун-та им. Н. Е. Жуковского «ХАИ». - Харьков, 2015. - Вып. 69. - C. $5-22$.

Поступила в редакцию 11.09.2018

\section{Метод створення моделей літаків за допомогою систем CAD/CAM/CAE і адитивних технологій}

Проведено аналіз набільш використовуваних у машинобудуванні адитивних технологій - моделювання методом пошарового наплавлення, селективне лазерне спікання, стереолітографія, пряме лазерне спікання металів. Наведено метод створення моделей літаків за допомогою систем CAD/CAM/CAE і адитивних технологій. Розглянуто результати застосування селективного лазерного спікання і пошарового наплавлення для виготовлення моделей навчально-тренувальних літаків.

Ключові слова: адитивні технології, селективне лазерне спікання, навчально-тренувальний літак, модель, майстер-геометрія.

\section{Method of creating airplane models using CAD/CAM/CAE systems and additive manufacturing}

The analysis of the most applicable in mechanical engineering additive technologies (fused deposition modeling, selective laser sintering, laser stereolithography, direct metal laser sintering) have been performed. Method of creating airplane models using $\mathrm{CAD} / \mathrm{CAM} / \mathrm{CAE}$ systems and additive manufacturing is presented. The results of the application of selective laser sintering and fused deposition modeling for the manufacture of training aircraft models are considered.

Keywords: additive technologies, selective laser sintering, training aircraft, model, master geometry..

Витязев Юрий Борисович - канд. техн. наук, президент ЗАО «Верификационные модели», Украина.

Гребеников Александр Григорьевич - д-р техн. наук, проф., зав. каф. 103 «Проектирования самолетов и вертолетов», Национальный аэрокосмический университет им. Н. Е. Жуковского «Харьковский авиационный институт», Украина.

Гуменный Андрей Михайлович - канд. техн. наук, доц. каф. 103 «Проектирования самолетов и вертолетов», Национальный аэрокосмический университет им. Н. Е. Жуковского «Харьковский авиационный институт», Украина.

Ивасенко Арсений Михайлович - аспирант каф. 103 «Проектирования самолетов и вертолетов», Национальный аэрокосмический университет им. Н. Е. Жуковского «Харьковский авиационный институт», Украина.

Соболев Александр Александрович - ассистент каф. 103 «Проектирования самолетов и вертолетов», Национальный аэрокосмический университет им. Н. Е. Жуковского «Харьковский авиационный институт», Украина. 